\title{
SMALL BUSINESS AND LABOR-RELATIONS PROBLEMS
}

\author{
Eddy S. Feldman*
}

Those who can find out what to do in organized business are scarce. Those who can find out how to do it are scarcer still.

\author{
Ggorge Bernard Shaw, Everybody's Political What's What \\ r35 (x945).
}

\section{INTRODUCTION}

To the extent that the labor-relations problems of "small" businessmen are distinguishable-in kind-from the labor-relations problems of "large" businessmen, they are so as much because of ignorance and lack of power as because of any fundamentally different treatment in law. Indeed, in relatively few areas in which the law treats of employment relations are there distinctions based upon the size alone.

Distinctions in statutory regulating schemes which are based upon size (perfectly valid constitutional distinctions, by the way ${ }^{1}$ ) may take the form of variations in volume of business, ${ }^{2}$ size of contracts with the federal government, ${ }^{3}$ number of

- LL.B. r94r, DePaul University. Member of the California and Illinois bars.

${ }^{1}$ New York v. Zimmerman, 278 U.S. 63 (1928).

3 The NLRB is empowered to prevent any person from engaging in certain unfair labor practices "affecting commerce." National Labor Relations Act $\$$ Io(a), 49 STAT. 453 (I935), 29 U.S.C. $§$ I60(a) (1952). This specific provision was left unchanged by the Taft-Hartley amendments. 6r STaT. I46 (1947). The Board may cede this power to state agencies by agreement with them if the state statute or construction is not inconsistent with the federal scheme. This statutory grant of power to the Board is most broad, but the Board has never exercised the full measure of its jurisdiction. For a number of years, the Board decided case-by-case whether to take jurisdiction. But in 1950, it concluded that "experience warrants the establishment and announcement of certain standards" which would govern the exercise of its jurisdiction. Hollow Tree Lumber Co., 9I N.L.R.B. 635, 636 (r950). And the Board then published standards, largely in terms of dollar amounts of interstate inflow and outflow. Press Release, October 6, 1950, 26 L.R.R.M. 50. In 1954, a sharply divided Board, see Breeding Transfer Co., I Io N.L.R.B. 493 (x954), revised the jurisdictional standards upward, thus removing many cases from the jurisdiction of the Board. Press Release, July 15, 1954, 34 L.R.R.M. 75. In Guss v. Utah Labor Relations Board, 353 U.S. I (I957), the Supreme Court noted, while denying access to an employer to a state agency with reference to a labor dispute covered by the National Labor Relations Act which fell under the existing jurisdictional standards, that there was a "vast no-man's-land, subject to regulation by no agency or court." Id. at to. The Court suggested that "Congress is free to change the situation at will," and that "the National Labor Relations Board can greatly reduce the area of the no-man's-land by reasserting its jurisdiction and, where States have brought their labor laws into conformity with federal policy, by ceding jurisdiction under Section IO(a)." Id. at II. The Board, in its Press Release of October 2, 1958, 42 L.R.R.M. 96, noted the Congress' approval of an appropriation requested by the Board which would allow the extension of the Board's jurisdiction in some of the uncovered area, and announced new standards:

I. Nonretail: $\$ 50,000$ outflow or inflow, direct or indirect. (Direct outflow refers to goods shipped or services furnished by the employer outside the state. Indirect outflow includes sales within the state to users meeting any standard except solely an indirect inflow or indirect outflow standard. Direct inflow refers to goods or services furnished directly to the employer from outside the 
state in which the employer is located. Indirect inflow refers to the purchase of goods or services which originated outside the employer's state, but which he purchased from a seller within the state. Direct and indirect outflow may be combined, and direct and indirect inflow may also be combined, to meet the $\$ 50,000$ requirement. However, outflow and inflow may not be combined.) (1954-\$50,000 outflow, \$500,000 inflow, \$ro0,000 indirect outflow, \$x,000,000 indirect inflow.)

2. Office buildings: Gross revenue of $\$ 100,000$ of which $\$ 25,000$ or more is derived from organizations which meet any of the new standards.

(1954-Employer who leases or owns and who operates must be otherwise in commerce and utilize building primarily to house its own offices.)

3. Retail concerns: $\$ 500,000$ gross volume of business.

(1954-Direct inflow of $\$ 1,000,000$, or indirect inflow of $\$ 2,000,000$ or direct outflow of \$100,000.)

4. Instrumentalities links and channels of interstate commerce: $\$ 50,000$ from interstate (or linkage) part of enterprise or from services performed for employers in commerce. (1954-\$100,000.)

5. Public utilities: $\$ 250,000$ gross volume, or meet standard I (nonretail). (I954-\$3,000,000 gross volume.)

6. Transit systems: $\$ 250,000$ gross volume. (Except taxicabs, as to which the retail $(\$ 500,000$ gross volume of business) test shall apply.)

(1954- $\$ 3,000,000$ gross volume.)

7. Nesuspapers and communications systems: Radio, television, telegraph, and telephone: \$ro0,000 gross volume. Newspapers: $\$ 200,000$ gross volume.

(1954-\$500,000 test for newspapers, $\$ 200,000$ for the others.)

8. National defense: Substantial impact on national defense.

(1954-\$100,000 in goods or services directly related to national defense, and pursuant to government contract.)

9. Business in the Territories and District of Columbia:

D.C.................... Plenary.

Territories.............. Standards apply.

(Same as r954.)

10. Associations: Regarded as single employer.

(Same as 1954.)

It appears that the Board may never get around to entering into any cession agreements because of the difficulty of complying with the conditions imposed on them by $\S$ ro(a). Guss v. Utah Labor Relations Board, supra. As to the validity of the Board's criteria for exercising jurisdiction, sce Hotel Employees Local No. 255 v. Leedom, 358 U.S. 99 (1958).

The maxim de minimis non curat lex may cause an administrative agency to refuse to take jurisdiction of a given situation over which it might normally be expected to exercise such jurisdiction. See, e.g., National Labor Relations Board v. Denver Bldg. and Const. Trades Council, 34I U.S. 675 (r951). The Attorney General for Pennsylvania argued before the Pennsylvania Supreme Court recently that a window cleaning company doing annually $\$ 40,165$ in volume of which $\$ 12,162$ was derived from services to 25 companies affecting interstate commerce would not be considered for relief by the National Labor Relations Board under the de minimis doctrine. 43 L.R.R.M. 7I (I958).

Under the Fair Labor Standards Act, minimum wage and overtime provisions do not apply with respect to employees working on newspapers whose circulation is less than 4,000 (if the major part of this circulation is in the county where it is published or in contiguous counties), to switchboard operators who work in public telephone exchanges which have not more than 750 stations, or to $\mathrm{cm}$ ployees or proprietors of telegraph agencies in exempt retail establishments if the telegraph message revenue of the agency does not exceed $\$ 500$ per month. 52 STAT. I067 (1938), 29 U.S.C. $\$ 213$ (a) (r952).

${ }^{3}$ Walsh-Healey Public Contracts Act, 49 STAT. 2036; 4I U.S.C. $\$ \$ 35-45$ (1952), which provides that any contract made by any department or agency of the United States, the District of Columbia, or by any corporation all the stock of which is beneficially owned by the United States for the manufacture or furnishing of materials, supplies, articles, and equipment in any amount exceeding \$10,000 must include provisions relating to the level of wages paid and overtime restrictions. A contractor may carry on business with the Government well in excess of \$ro,000 and still not be subject to the Act, so long as no one contract exceeds $\$ 10,000$. 
personnel employed, ${ }^{4}$ number of employees covered under pension and welfare plans, ${ }^{5}$ and the specific activity of the employer, which may incidentally and by its nature be "small." These various distinctions imply "smallness" versus "bigness," and while it would ease this analysis by having at hand a convenient, arbitrary definition of small business, there is really no completely satisfactory way of dividing employers into these two groups. Perhaps it will prove adequate merely to refer to these two classes as though one knew exactly which they embrace and leave it to the individual entrepreneur to choose the more fitting description for himself.

Having, however, set out these few instances in which size of the employer may determine whether a given statutory scheme may apply to him, we are thrown back to discovering the basic reason why one should discuss small business labor relations problems at all. Are they really different in kind from the problems of larger business?

To a practitioner, it does not appear that such labor problems as a small businessman may have are different radically from those of his larger counterpart. What does appear to be different is the variation in attitudes and methods of solving these problems. These seem to spring from the fact that smallness implies some other characteristics which enter dynamically into the problem situations. As we noted before, smallness frequently implies less knowledge of management techniques and of legal rights, duties, and remedies. It also implies a lesser residuum of "power" in the individual employing unit. ${ }^{7}$ These two characteristics of smaller business can, and do, justify some distinctive descriptions of small business labor problems. ${ }^{8}$

\section{Noncollective Bargaining Problems}

In the first place, it may be well to separate the field into collective bargaining problems and all other labor-relations problems. For the most part, the small

'INT. REv. Code of 1954, $\$ 3306$ (a), provides that the only employers subject to the Federal Unemployment Tax Act are those who employ four or more persons for not less than twenty days each year.

6 The provisions of the recently passed Welfare and Pension Plans Disclosure Act, 72 Stat. 998 (I958), 29 U.S.C.A. $\$ 303$ (b)(4) (Supp. I959), effective January I, I959, are not applicable to employee welfare or pension plans if they do not cover more than twenty-five employees.

o Note, e.g., in California, the exclusions from unemployment insurance coverage of "domestic service in a private home," "services performed as a real estate, business opportunity, mineral, oil or gas, or cemetery broker or salesman by an individual who is licensed in one of such classes by the State and who is remunerated solely by way of commission," and "services performed [by an individual as a golf caddy] in caddying or carrying a golf player's clubs." CAL. UNEMPLOYMENT INs. CODE, div. I, pt. I, art. $2, \S \S 629,650,651$. See also National Labor Relations Act, supra note 2, $\$ 2(3)$.

${ }^{7}$ See the interesting, if not always pellucid, papers presented at the $1958 \mathrm{Meeting}$ of the Industrial Relations Research Association on the theme, Power in Industrial Relations-Its Use and Abuse, published in 9 LAB. L.J. $6 \mathrm{I}_{5} \mathrm{et}$ seq. (1958).

${ }^{8}$ The identity of ownership and management in the small business, in contradistinction to their separation in the larger corporation, will also help explain the differences in viewing labor-relations problems. 
businessman is not unlike all other businessmen when it comes to whether he must, under the appropriate criteria, pay a premium for overtime work, pay not less than a minimum wage, refrain from hiring minors, provide safe, healthful, and comfortable conditions of employment, ${ }^{9}$ pay taxes for unemployment compensation benefits, buy insurance to cover the claims arising from injuries of his employees on the job, or not discriminate in hiring because of race, creed, or color. Unless he is outside the application of the legal standard for some "nonsize" reason, he has the same obligations as any other employer.

The small businessman's troubles begin when, because of lack of knowledge of the obligations imposed upon him by statute or by the law of the collective bargaining agreement to which he may be a party, he fails to live up to those obligations and he is called upon by someone-an aggrieved employee or a governmental agency-to conform to them. (This is not to gainsay that the small employer may well know his obligations and intentionally seek to avoid them. Certainly such attitudes do exist: an employer may be looking for gain for himself or he may be driven to his actions by a desire to remain in business if he is not able to see any other way of doing so. There probably can be no abstract justification for deliberate lawevasion when the legislative body has decreed the obligations which must be met by any entrepreneur who wishes to employ people in his enterprises.) He may have a general knowledge of his obligations but be trapped into specific error by his unawareness of nonobvious interpretations of law by administrators or courts of both.

A good illustration of the opportunity for expensive error is the overtime provisions of the Fair Labor Standards Act. Section $7(a)$ of that statute requires that a covered employee shall receive compensation for hours worked in excess of forty "at a rate not less than the regular rate at which he is employed." The Administrator of the Wage and Hour Division has interpreted this to mean that where employees are compensated on an incentive earnings basis, the regular rate of pay is the rate found by dividing the hours worked in the work week into the total earnings during this same period. ${ }^{10}$ Now, most collective bargaining agreements contain specific hourly rates for the various job classifications covered in them, and these will generally be lower than the average hourly rate computed for "pieceworkers." (Even in the absence of a collective bargaining agreement, an employee is usually hired in

\footnotetext{
Where there is this identity, there is a tendency to accept a solution of expediency and to work out a modus operandi in as resourceful a way as possible. For a provocative discussion of the significance of the separation of ownership and management, see Adolf A. BERLE, JR., Economic POWER AND THE Free Society, a Preliminary Disctssion of the Corporation (1958).

o "It shall be the continuing duty of the Industrial Welfare Commission . . . to ascertain the wages paid and the hours and conditions of labor and employment in the various occupations, trades, and industries in which women and minors are employed in this State, and to investigate the comfort, health, safety, and welfare of such women and minors." CAL. LABOR CODE $\$$ II73. "Every employer in any establishment employing any female, shall provide suitable seats for all female employees and shall permit them to use such seats when they are not engaged in the active duties of their cmployment." Cal. LABOR CODE $\$$ I253.

${ }^{10} 29$ C.F.R. $\$ 778.3$ (b)(2).
} 
at some stated time rate, with an understanding that he should be able to earn more by the operation of the incentive system. In any case, the covered employee may not be paid less than the statutory minimum wage.) It has not been unknown, however, for an employer to use the "straight" hourly rates for the computation of overtime premium, because he could quite reasonably conclude that "regular rate" in the statute (if he is inclined to reading statutes) means an unchanging rate from week to week. The Administrator's interpretation in this instance has stood the tests of litigation and subsequent congressional review, ${ }^{11}$ but these subtleties are not necessarily part of the stock of managerial knowledge possessed by small entrepreneurs.

Unquestionably, operating any business in today's complex society is an intricate art which requires knowledge of many disciplines, together with the administrative ability to integrate them and apply them to the enterprise. Running a small business requires no less knowledge, but even this fact eludes the small businessman. The small entrepreneur many times is not at all aware that he has any problems-until it is too late. And granted the knowledge of problems, there may be-and usually is-a reluctance to spend the money to acquire people with the expertise to overcome the lack of information.

One may assume that the smaller businessman being discussed here is not himself a professional accountant or lawyer. On the one hand, he will employ bookkeepers and auditors as a matter of course. More likely than not, on the other hand, he will retain legal counsel only when trouble has arisen. No matter why this reluctance to seek preventive legal advice, ${ }^{12}$ he is usually well on his way to legal trouble when he gets round to retaining counsel.

It may be concluded, therefore, that in ordinary noncollective bargaining situations, knowledge of obligations is the important thing in employment relations. ${ }^{\mathbf{1 3}}$ The small businessman has many sources available for the acquisition of knowledge: administrative agencies; trade associations and chambers of commerce; ${ }^{14}$ professional advice of lawyers, accountants, and business consultants; business services; and other publications. Experience teaches one that many small businessmen do not avail themselves of these aids, and until they reach an understanding that knowledge is strength, and probably money as well (even if only in the sense of penalties not incurred), they will continue not availing themselves of the knowledge.

\footnotetext{
${ }^{11}$ For a review of this matter, sec Feldman, Algebra and the Supreme Court, 40 ILI. L. REv. 489 (1946).

19 The useful concept of preventive law which contemplates a periodic "legal check-up" has been developed in great depth by Lours Brown, Manual of Preventive Law (r950), and has been effectively applied in his valuable book, How to Negotiate a Successful Contract (1956). See, also, Louis Brown, Your Legal Facts: Inforasation for Your AtTornex (American Bar Foundation, Reproduction Ser. No. 3) (1957).

${ }^{18}$ The small employer should not overlook the usefulness of good personnel practices. See FranCEs B. Torbert, Personnel Management in Samall Companies (i958).

"See William Smith, Local Employers' Associations (I955).
} 


\section{Coliective Bargaining. Problems}

When we contemplate the small businessman and collective bargaining, we enter another world, almost, where knowledge is, of course, vastly important, but where accretions of power will determine the course along which the small businessman will go.

Whether he is organized or not, the small businessman is concerned with collective bargaining. If he has a choice of location, he is likely to avoid an area where union organization is prevalent. But other considerations may determine location: the desire to live in a certain city or part of the country, availability of materials, existence of a skilled labor supply, and access to customers. In the latter situations, the entrepreneur may have more immediate concerns with union organization.

If he is confronted with an organizational campaign among his employees, or if he is simply asked to sign a contract without consultation with or consideration of the wishes of his employees, he is faced with the necessity for making decisions he is quite possibly ill-equipped to make. While it is not invariably true that an employer will seek to avoid organization, it is probably the case that he would regard himself better off without it. His first inclination is to resist organization, and it is at this point that his need for knowledge becomes acute and that he should become aware of the necessity of evaluating his own power residuum. In the absence of any applicable labor relations statute, he may rely on his own knowledge and upon his own evaluation of the power relationships, and he may not fare badly. However, he is not likely to know the extent of the proscriptive restrictions on his own actions if he is an employer covered by a labor relations statute at some level. For example, during an organizing campaign he may discharge some employees wrongfully and unwittingly incur expensive back wage payments. He could possibly have achieved his same objectives by communicating with his employees, but he may have refrained from this course of action under a misconception that he must maintain complete neutrality. ${ }^{15}$ Even the answer to the threshold question of whether he is a covered employer will dictate the appropriate course of action. If it is answered incorrectly, the results may be costly.

When the organizing group is seemingly unable to obtain a majority of employees to join it (as evidenced by its unwillingness to go to a representation election to be conducted, say, by the National Labor Relations Board) an employer may himself want to go to the Board. But he may find that this is not as simple as it sounds. First, as we have already seen, the Board's jurisdictional standards may exclude him from its services. Then, even if he gets there, he may find that the delay due to dilatory moves by the union or other participants or by virtue of the agency case-

\footnotetext{
${ }^{15}$ Where an employer had rules against the solicitation of any kind on company property and the distribution of literature or posting of signs and it enforced them during an organizational campaign of competing unions, but where it distributed eight pieces of antiunion but noncoercive literature, the employer was guilty of an unfair labor practice. United Steelworkers of America v. NLRB, 243 F.2d 593 (D.C. Cir. 1956).
} 
load is as damaging to him as if there were no agency. True, in some cases, Board procedure may be speeded up because of the nature of the dispute; ${ }^{\mathbf{1 6}}$ yet, in the case of the small businessman, any delay may be hurtful, if not fatal.

Quite possibly, the employer may not wish his case to be in Board hands, at all. If the organizers feel they have a majority, they will file for a representation election. In this event, the employer may wish to be free of Board interference, because he will want to be able to handle his own problems without governmental intervention. A broadening of the Board's jurisdictional standards in this case will not be desirable if the employer wishes to exercise his rights in accordance with local law. The existence of the so-called "no-man's-land" does not displease or inconvenience this employer. It is difficult, therefore, to generalize as to what course of action in this respect should be taken by government, ${ }^{17}$ although what is thought by the community to be good for big business labor relations should be no less good for small business labor relations.

One might naturally suggest that the administrative delay be reduced, although one man's delay may be another man's obtaining of justice. ${ }^{18}$ Delay is not uniquely a small business problem, though, for it plagues the larger business, too.

It is always problematical how long any employer of limited resources in a relatively well-organized community can withstand a determined organizing effort. ${ }^{19}$ Not that every small employer need collapse and beg for the best possible contract whenever a union organizer shows up at his factory or store. Nevertheless, the cost of resistance may be high, ${ }^{20}$ and unless the employees show determined refusal to succumb to the blandishments of the organizers, few small employers can sustain the pressure. ${ }^{21}$

${ }^{10} \mathrm{As}$ in secondary boycott cases, where the NLRB must give priority to charges filed under $\S$ Io(I) of the National Labor Relations Act, 49 STAT. 453 (I936), 29 U.S.C. \$ I60 (1952).

${ }_{17}$ The Small Business Administrator had at one time thought that the NLRB should broaden its standards considerably more than it eventually did. He apparently communicated this concern to the Board, as reported in the Washington Post and Times Ferald, Sept. 4, 1958, p. D7, col. 8. Later he appears to have indicated that the Board's proposed standards were too encompassing. Column of Drew Pearson, Los Angeles Mirror-News, Nov. 4, I958, p. I9, col. 7-8.

${ }^{18} \mathrm{Or}$ as the executive secretary of the NLRB has put it: "... one man's red tape is sometimes the other man's due process." Hearings Before the Senate Select Committee on Improper Activities in the Labor or Management Field, 85th Cong., 2d Sess. pt. 4I, at 1569x (1958). The statement was made in conjunction with hearings into the matter of a trucking company (with seven employees) which complained that it was forced out of business (apparently due to secondary boycotts) while representation proceedings were pending before the Board.

${ }^{20}$ The organizing techniques are varied. Unorganized small merchants, for instance, in shopping centers may find the entire shopping center is being picketed. Amalgamated Meat Cutters v. Fairtown Meats, Inc., 353 U.S. 20 (1957); Note, Shopping Centers and Labor Relations Law, ro Stan. L. REv. $694(1958)$.

${ }_{20}$ See testimony before the Senate Select Committee on Improper Activities in the Labor or Management Field that the Southwestern Motor Transport had lost $\$ 1,000,000$ through a boycott that began in 1954. N.Y. Times, Nov. 18,1958, p. 27, col. I.

${ }^{22}$ Some do. See the testimony of the President of the Galveston Truck Lines, Inc., before the Senate Select Committee on Improper Activities in the Labor or Management Field, describing his energetic activities and extensive litigation, while the Teamsters Union sought to organize his company, against the hot-cargo clause, before the Interstate Commerce Commission, and under the Taft-Hartley, Sherman, and various state antitrust acts. Hearings, supra note 18 , at I5597-625. 
Once the small employer is organized, or he has agreed to recognize the union, a contract must be worked out and an entirely new set of problems confronts him. Again, the relative lack of knowledge, experience, and power will work to his detriment unless he takes steps to acquire the knowledge and neutralize the complex of power. And, again, the problems of the small employer are different only in degree from those of the larger employer. They will take their form from many external factors, such as the extent of collective bargaining in the area and in the trade or industry of which the employer is a part, the relationships between production and teamster employees and their unions, the responsibility of local union leadership, the attitude of the entrepreneur, and his ability to pass on increased costs to his customers.

Knowledge of what conditions the union has obtained from other employers in the industry is absolutely essential so as to enable the employer to negotiate from a position of some strength. Obtaining this knowledge may be difficult, until one joins an employers' organization. The appropriate association will be able to supply knowledge about working conditions and, if it engages in collective bargaining, to enhance power through joint efforts and employer solidarity. ${ }^{22}$ Unfortunately, small employers frequently do not know of the existence of such organizations ${ }^{23}$ until the fact situation becomes irretrievable; or they are unwilling to spend a little money for counsel in trying circumstances. But lack of knowledge and power in negotiating will lead to needlessly higher wage rates and more onerous administrative conditions, as well as to restrictions which may deprive the employer of needed freedom to adopt techniques of production ${ }^{24}$ and compensation which will enable him to survive. Joint collective bargaining on the employers' side will at least lead to consistent contract terms for every employing unit; and if the group is confronted with the ultimate weapon-the strike-the possibility that all employers will shut down if one of them is struck may conceivably act as a restraining influence on the union.

In areas where unions are strong (and where teamster union power in combination with other unions is great), the hapless employer is often at their mercy when it comes to negotiating contract terms. While there may be a trend to uniformity and a development of "patterns" on the part of the settlements, unions are in a real sense limited in the wages and conditions they may exact by their knowledge that if some limit is exceeded, the employer will be forced out of business and the union members will lose their jobs. Employers cannot rely on these limitations on unions, though, and power must be faced with power.

\footnotetext{
${ }^{22}$ In addition to the literature referred to in NLRB v. Truck Drivers Local Union No. 449,353 U.S. 87, 95-96, nn. 23, 24, 25 (1957), see Jesse T. Carpenter, Employers' Associations and Collective Bargaining in New York City (1950); Clarence E. Bonnett, History of Employers' Associations in the United States (I956); Henry W. Ehrmani, Organized Business in France (x957).

${ }^{23}$ Some unions may indicate to a newly-won shop that it should join a given employers' association and thus obtain a "standard" industry contract.

${ }^{24}$ See the attack on "methods-time-measurement" (M-T-M) by the Upholsterers' International Union. UIU Journal, July 1958 , p. 4 .
} 
By combining employing units, small employers may wield great power. ${ }^{25}$ The problem is getting the small employers to get together in the first place and getting them to remain together in the face of negotiating crises. In the latter instance, it may be difficult to keep the group from breaking up for any length of time because of financial instability or because of sheer opportunism on the part of individual employers.

\section{Conclusion}

Smaller employers have the same labor relations problems, we now see, as larger employers. The problems differ in degree only, not in kind. But the approach of the small businessman unused to employing professional counsel will be relatively unskilled and less farsighted than that of his larger counterpart.

Essentially, the course for the small businessman is clear: he must obtain knowledge and power. If he is to be successful, he must work at this quest just as much as at any other phase of his business, be it design, finance, or sales. And he must be prepared to pay for this knowledge and power, just as he would for any other element of his enterprise. There need be no special legislation, special agencies, special counsel for any small businessmen in this area of activity. There must be only a special desire and special effort to acquire the knowledge and strength needed for carrying out any policy decisions which the small businessman may have made. ${ }^{26}$

${ }_{25}^{25}$ The union struck one member of an eight-member employer bargaining association as part of a "whipsawing" strategy. The next day, the other seven members laid off their employees, whereupon the union subsequently filed an unfair labor practice charge with the NLRB. The Supreme Court upheld the employers' actions. "Although the [National Labor Relations] Act protects the right of the employees to strike in support of their demands, this protection is not so absolute as to deny self-help by cmployers when legitimate interests of employees and employers collide. Conflict may arise, for example, between the right to strike and the interest of small employers in preserving multi-employer bargaining, as a means of bargaining on an equal basis with a large union and avoiding the competitive disadvantages resulting from non-uniform contractual terms. The ultimate problem is the balancing of the conflicting legitimate interests. The function of striking that balance to effectuate national labor policy is often a dificult and delicate responsibility. ..." NLRB v. Truck Drivers Local Union No. 449,353 U.S. 87,96 ( 1957 ). Under similar circumstances, it is quite likely that unemployment insurance benefits will not be awarded to the locked-out employees. Feldman, Unemployment Insurance: Its Effect on Trade Disputes in California, 5 U.C.L.A. L. Rev. 604 (1958).

${ }^{20}$ Mrzes L. Mace, The Board of Directors in Sarale Corporations (1948). "Though every individual is unique and different, separate laws cannot be made for every individual; therefore, the individual must fit himself to the law instead of having it fitted to him." George Bernard Shaw, Everybody's Political What's What? I92 (I944). The special counsel of the AFL-CIO, Mr. Arthur J. Goldberg, has suggested the creation of a government-sponsored Labor-Management Assembly. The "present membership of the Business Advisory Council, enlarged by representative small businessmen [should] constitute the industry representation." AFL-CIO News, Nov. I5, 1958, p. 6, col. 3. Provided that such a body could serve a constructive purpose, it would certainly give more validity to the Assembly's conclusions. 